
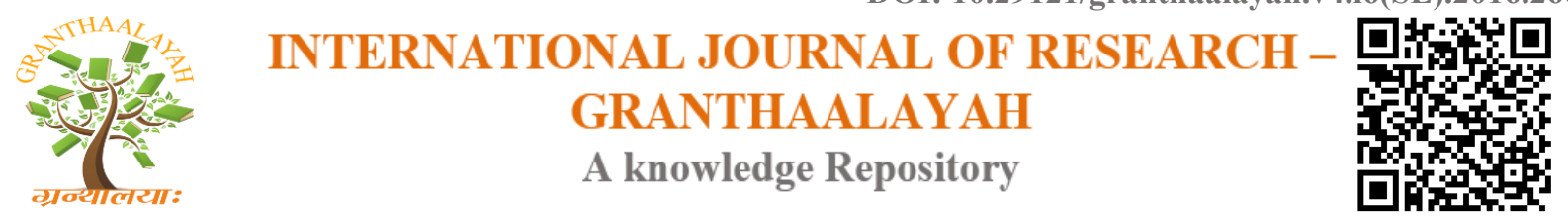

Management

\title{
A STUDY ON LOAN PORTFOLIO MANAGEMENT OF URBAN COOPERATIVE BANKS IN TAMIL NADU
}

\author{
G.Sathish *1 \\ ${ }^{*}$ Ph.D. Research Scholar, Department of Cooperation, Gandhigram Rural Institute, \\ Gandhigram, Dindigul District, Tamil Nadu, INDIA
}

\begin{abstract}
Cooperative Banking System has two broad systems i.e. urban and rural cooperatives, forms an integral part of the India's Financial System. Urban Cooperative Banks play an important role as financial intermediaries in catering to the credit requirements of both priority sector and weaker section of the communities. As on March 2015 there were 120 UCBs functioning all over Tamil Nadu and the majority is Non-Schedule UCBs. These banks are traditionally centered on communities, localities and work place groups, and they lend to agriculture and non-agriculture purpose and particularly to small farmers, small traders, business man, artisans, factory workers, salaried people and persons of small means. This paper highlights the per-stage and post-stage sanction of loan process of credit in Tamil Nadu Urban Cooperative Banks. Further, the paper makes an assessment of the extent to which Urban Cooperative Banks were following loan portfolio management and identifies the focus area of improvement in near future.
\end{abstract}

Keywords:

Pre-stage, Post-stage, Portfolio Management.

Cite This Article: G.Sathish, "A STUDY ON LOAN PORTFOLIO MANAGEMENT OF URBAN COOPERATIVE BANKS IN TAMIL NADU" International Journal of Research Granthaalayah, Vol. 4, No. 6: SE (2016): 73-78.

\section{INTRODUCTION}

The credit system is the most important factor of banking sector. If the credit system is not strong then its results would be serious on the society and consequently on the economy of the country. To make the bank financially competent and strong, it's necessary to follow strict rules, regulation and guidelines while sanction loans. 


\section{STRUCTURE FOR CREDIT MONITORING PROCESS}

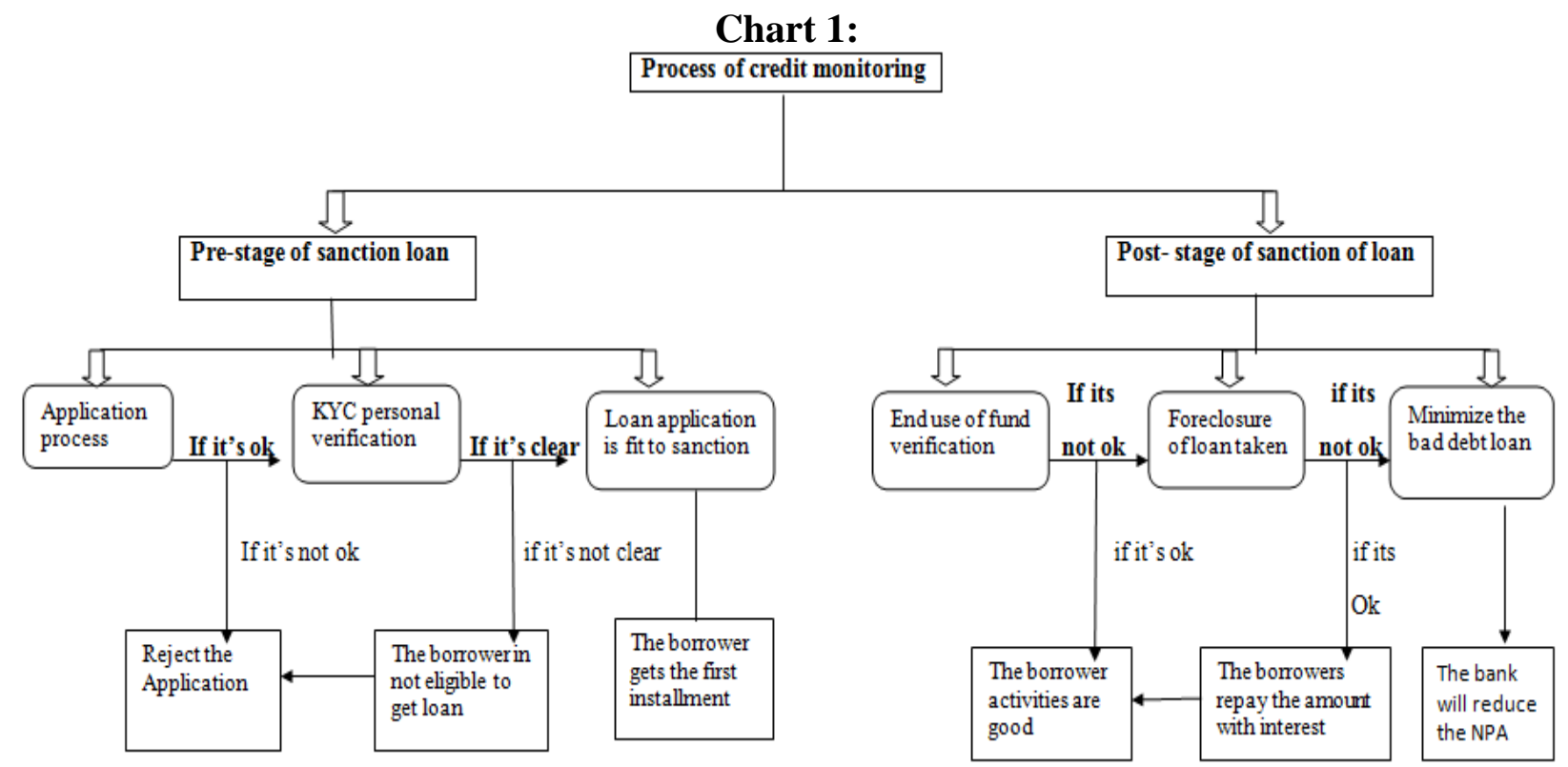

\section{Pre-stage of sanction loan}

The bank must frame the structure of pre- stage sanction for the borrowers it will help full to the bank whether the borrower is default or not on this credit monitoring basis the loan will issue.

- Application process

- KYC of personal verification

- Loan application fit to sanction for the borrower

\section{Application process}

1) Loan application must not faulty

2) It should be complete, clearly and neatly written. Along with an application necessary documents should be submitted.

3) In the loan application information of the borrower and guarantor must be true, correctly and duly signed

4) When the loan application is submitted bank manager and other official should verify the information. Both borrower and guarantor should be called together and discuss with them at a time

5) In verification borrowers and guarantors Name, address, age, address, of the native place, profession, monthly income, their status etc. should be confirmed while discussion.

6) Motive of seeking loan, borrower's background, need for which he is taking, whether eligible or not, present residence and would stay till recovery of the loan, all these points should be discussed and confirmed.

7) The credit risk Frame work (CRF) specifies the nature and number of grades to be used. The grades in rating scale indicate the level of risk associated in each credit transaction. Banks may have a numerical scale (say 1-8) or a grading scale (say AAA,AA,A,BBB) or an alpha numeric scale for each given. For each given grade a quantitative definition of the borrower, the loans underlying financials of the borrower may be presented in the 
CRM policy document. The borrowers having high credit rating score reflect high credit worthiness whereas low scores show poor credit worthiness

\section{KYC of personal verification}

Visit should be arranged to the project to verify the reality. Following point should be considered during this visit.

1) Name of the borrower, address, age, profession, contact, mobile, phone number, etc., monthly income, nature of project whether temporary or permanent condition, past view, supporting documents. Borrower's financial position in other banks and status.

2) Whether the project is in profit or loss and its reason and to estimate the project value and the banker to analyze the overall project amount

3) Supplier of the raw material, distributor, customer, quality of the goods, and turn over, all these points should be confirmed.

4) Details of loan amount for which reason is required and its use (present and future plans) whether it is profitable or not, percentage, what way, how much and period.

5) Marketing strategy, rates, consequences in future, which way it would affect, whether project would survive in future. Status of the borrower in the market. Consequences on the goods in future. Sales of goods, expenditure for sell, profit, its continuity, these points should be considered minutely

6) Borrowers outstanding and debt, in past, present and future, capital investment in past present and future in what way it was raised, comparative analysis should be reviewed

7) In short scrutiny of the project of the borrower should be made thoroughly

8) Valuation of collateral security, assets, procedure of realistic valuation, addition assets, its type, insurance, all these factors should be confirmed

9) Other divisions or sister concern of the project must be verified

10) Repayment of loan of the borrower must be monitored

\section{Loan application fit to sanction for the borrower}

1) After scrutiny of the borrower loan application with guarantor also discussion should be made on the above credit on progress points

2) As per the loan policy of the RBI (bank oriented) and Scrutiny of the information loan may be sanctioned and if he is eligible for loan the recommendation should be made otherwise not.

3) There should not be any pressure on loan verification officer. Loan verification officer should also recommend the proposal without prejudice

4) Manager should go through the application appraisal minutely and should correct it if any, without any penalty and without any pressure recommended the proposal according to the rules and submit in the meeting of the board of directors approval

5) Board of directors also should approve the loan proposal with a view to benefit the bank and the borrower ultimately of the society

6) After (allocation of loan) sanction borrower should be informed in writing.

7) Before withdrawal of sanctioned loan all terms and conditions should be fulfilled by the borrower. If there is any problem must be solved and should not pressurized by the higher authorities 
8) Before withdrawal both borrower and guarantor should come in the bank and sign the documents on stamp paper.

9) Advance should be granted as per requirement of the borrower and acknowledgement receipt should be given to the borrower.

\section{Post stage of sanction loan}

Once the borrower can get the loan amount after the banker should monitor the customer activities and if customer loan are over dues mean in that the banker will follow the customer how to recover the loan amount and to safe the bank image and reduce the minimum level of NPA.

i. End use of fund verification

ii. Foreclosure of loan taken

iii. Minimize the bad debt loan

\section{End use of fund verification}

1) Borrower should repay installments on time and submit the balance sheet to the bank in time

2) Banks may strengthen their monitoring system by resorting more frequent inspections of borrowers project. UCBs should take appropriate steps to review and tighten their internal administration and control measures so as to eliminate the scope for misuse/ diversion of funds and malpractices.

3) Special officer should be appointed to submit progress report to the branch. Any mistake should be rectified account showing sing of turning into NPA, bank may put in place more stringent safeguards. Head office should discuss the matter and give proper advice and directions and should not file the report.

4) If installment is delayed even by a day, contact the borrower, issue letter, to recover installment, penal measures should be executed.

5) It is necessary to have control of branch level on borrowable account.

6) Nonpayment of three installments may immediately submit to file suit with outstanding amount to the recovery department

\section{Foreclosure of loan taken}

1) Objective of the recovery department should take precaution of the accounts turning into NPA and not only to take action on the defaulter

2) There should be certain norms of the working system of the recovery dept. and according to that work should be completed in time.

3) There should not be any interference or pressure in the work of recovery officials not to recover the outstanding amount

4) Adequate facilities should be provided to recovery officers of the bank for the official work

5) In the working time recovery officer should honestly work for the recovery and not for another work

6) In loan and recovery dept. advance technology should be adopted. In these depts. there should be atmosphere or mutual understanding, continuity, cooperation, mutual helping to each other 


\section{Minimize the bad debt loan}

1) Government and related establishment should co-operative for the recovery from time to time

2) Procedure in execution of decrees and orders should be implemented by the recovery officer, immediately

3) Important objective in loan dept., recovery debt and legal department are guidance, control, continuity, supervision and regular follow ups it should be implemented without fail

4) Banks to avail of facilities, schemes all the govt. it may help to minimize the bad debts

5) In exceptional cases if any willful defaulter could not repay installments, but now if his financial position is good and in future also it would remain good then the loan amount should be reconstructed to new loan account that of old one. New advance proposal should be regularized. Bank should take initiative in this regard

6) Special loan schemes for small scale and cottage industries and local self helps group should be made available. Guidance should be provided which help to minimize the bad dept and increase the no. of loan proposals

\section{CONCLUSION}

If the above processes are implemented at right time and in right way will be certainly reduce the NPA and benefit to the urban cooperative bank.

\section{REFERENCES}

[1] Akbar, M. M., \& Parvez, N. (2009). Impact of service quality, trust, and customer satisfaction on customers' loyalty. ABAC Journal, 29(1).

[2] Anuj arora "bench marking credit risk Management operations and systems at transaction level” journal of Prajnan vol. XL, No.2,2011-12

[3] Dr. C. Eugine Franco, and Regi. S Bulomine, "Advantages and Challenges of ECommerce Customers and Businesses: In Indian Perspective” International Journal of Research-Granthaalayah, Vol. 4, No. 3: SE (2016): 7-13.

[4] Golden, S. A. R. (2015). Regional Imbalance affecting quality of e-banking services with special reference to Tuticorin District-An Analysis. International Journal of Research, 2(3), 788-798.

[5] Golden, S. A. R., \& Regi, S. B. (2015). Satisfaction of Customers towards User Friendly Technological Services offered by Public and Private Sector banks at Palayamkottai, Tirunelveli District. International Journal of Research, 2(3), 775-787.

[6] Golden, S. A. R., \& Regi, S. B. Mobile Commerce in Modern Business Era.

[7] John D.Silva "Co-operative Bankers" Hand book cum diary,(2014), KYC Norms Page No (232).

[8] K.L phale and vardha "Finance management and sanction of advances" journal of TDS issue -6th Feb- march 2015

[9] MANAGEMENT OF ADVANCES-Master Circular On-(Ref:UBD.BPD.(PCB)MC No.5 dated 01/07/2013 
[10] Regi, S. B. \& S, A. R. G. (2014). “A DESCRIPTIVE STUDY ON THE ROLE OF CONSUMER PSYCHOLOGY AND BEHAVIOUR IN PRODUCT PURCHASING". Indian Streams Research Journal, 3.

[11] Regi, S. B., \& Golden, S. A. R. (2014). Attitude of Rural People Towards Technology Inclusion In Banking Services At Tirunelveli District. IGJAE - Indo Global Journal Of Applied Management Science, 2(2).

[12] Regi, S. B., \& Golden, S. A. R. (2014). Foreign Direct Investment- An Overview. IJARCSMS, 2(2).

[13] Regi, S. B., \& Golden, S. A. R. (2014). Reforms In Insurance Sector In India- A Empirical Study. Review Of Research, 3(9), 1-5.

[14] Report of the export committee on licensing of new urban cooperative banks 2011. 